\title{
"Here's a man and a woman sitting on a rock": Joni Mitchell, Margaret Atwood, and Irritable Feminism
}

Pamela Thurschwell

In this chapter I chart multiple connections between Joni Mitchell and Margaret Atwood, as brilliant, angry, self-conscious, Canadian women artists of a similar generation. ${ }^{1}$ I explore the crossovers between Mitchell's songs (focusing on "Come in from the Cold," "Song for Sharon," and "Refuge of the Roads") and Atwood's writings (focusing on the quasi-autobiographical novel, Cat's Eye) to uncover a shared sensibility as well as a shared history and sense of place. Mitchell's and Atwood's works speak to each other through a similar affective landscape--simultaneously tough, vulnerable, and imbued with a desire for freedom that merges with a deep sense of loneliness. A critique of patriarchy, via a feminism that I want to call irritable, is a central plank of both authors' techniques and sensibilities.

Mitchell and Atwood's work in relationship to feminism can be seen to provoke irritation in two different directions. First, feminist fans, such as myself, might find ourselves occasionally irritated at both of these hugely admired artists for their periodic refusals to inhabit the word 'feminist', which we want to assign to them. Second, Mitchell and Atwood sometimes seem annoyed, in return, by fans' desire to annex them and their work. They regularly express their desire not to be pinned down by any one term such as feminist. There is a relationship then of mutual, but I'd like to think, productive, irritation between Mitchell and Atwood and their feminist fans. At the end of the chapter, I will connect this dynamic of shared irritation to Mitchell's sense of humour, which is often overlooked because it often appears in relation to her dissatisfaction with a heterosexuality she is also constantly drawn back towards, as both a good and bad object. Joni's optimism (what there is of it) is, in 
Lauren Berlant's terms, cruel but also wry; she and Atwood both cast sidelong, sceptical glances at their own nexus of desires and its structural impossibility. ${ }^{2}$

Making the case for irritable feminism, or indeed, any sort of feminism, as central to understanding Mitchell and Atwood's artistic output, is complicated by the fact that both artists have had an ambivalent relationship to feminism throughout their careers. Mitchell more vehemently than Atwood has disavowed the label 'feminist' in relation to her work. To take just one example, in an interview with Malka Marom in 1973, Mitchell claims "I was never a feminist. I was in argument with them. They were so down on the domestic female, the family, and it was breaking down. And even though my problems were somewhat female, they were of no help to mine. I was already past that. I don't want to get a posse against guys." ${ }^{3}$ Similarly, echoing a familiar disavowal of an anti-male feminism in favour of an apparently more encompassing "humanism," Atwood too has expressed some dissatisfaction with the term. Most recently, in relation to the TV series of The Handmaid's Tale, she found herself again being asked about the feminist credentials of the novel, and again demurring. ${ }^{4}$. In Rebecca Mead's profile of her in a 2017 New Yorker piece, Mead explains the paradoxes of this in relation to Atwood's work:

Given that her works are a mainstay of women's-studies curricula, and that she is clearly committed to women's rights, Atwood's resistance to a straightforward association with feminism can come as a surprise. But this wariness reflects her bent toward precision, and a scientific sensibility that was ingrained from childhood: Atwood wants the terms defined before she will state her position. Her feminism assumes women's rights to be human rights, and is born of having been raised with a presumption of absolute equality between the sexes. "My problem was not that people wanted me to wear frilly pink dresses - it was that $I$ wanted to wear frilly pink dresses, and my mother, being as she was, didn't see any reason for that," 
she said. Atwood's early years in the forest endowed her with a sense of self-determination, and with a critical distance on codes of femininity - an ability to see those codes as cultural practices worthy of investigation, not as necessary conditions to be accepted unthinkingly. ${ }^{5}$

Atwood's occasionally grumpy relationship to feminism is here posited as a product of the unusual freedom in her upbringing; her father was an entomologist and, like the character Elaine in Cat's Eye, Atwood spent her early years travelling with her parents in the woods of Northern Quebec while he did research, her family finally settling in Toronto when she was eight. ${ }^{6}$ Atwood's refusal to identify herself with a single identity category can be connected, via this analysis of her early years, to an anthropological distance that her narrators maintain in many of her works. It can be found, for instance, in the metafictional academic-conference epilogue to The Handmaid's Tale, which interrupts the trauma and immediacy of Offred's story and replaces it with academic infighting and historical distance. Cat's Eye also sets up its protagonist, Elaine as a kind of anthropologist. The reader witnesses the young Elaine's struggles to understand the codes of adolescent and adult femininity that surround her in her new environment. Elaine's estrangement from these codes also estranges us as readers; why, the book asks, would anyone find it desirable to wear a "twin set" or even know what one was $?^{7}$ But then again, why be denied a twin set, or a frilly pink bow, if you want one? When does freedom from the trappings of femininity actually turn into another demand that the young woman perform her feminism, and her gender, a certain way (without make-up or frilly pink bows)? As the previous quote from Mead indicates, Atwood sees femininity as a performative structure, viewing it from a critical distance; in Cat's Eye she both questions the efficacy of, and exposes the cruelty of, gender policing. However, in other sections of the novel, when the grown-up Elaine is a painter claimed by 1980s Toronto feminists, she also bristles at a different kind of policing -- that which would make her a spokesperson for 1970s 
second wave feminism. When Elaine is interviewed by a young woman reporter, she is asked about her debts to feminism, "A lot of people call you a feminist painter". Elaine responds: "I hate party lines, I hate ghettoes." 8

Neither Mitchell nor Atwood are comfortable being pinned down, then, in relation to their gender and sexual politics. Although they are both often tough and hard-headed in their dissections of patriarchy, romantic love, and the ruses of heterosexuality, they are also often unforgiving in their representation of dynamics between women. ${ }^{9}$ I'd like to place this shared attitude in relation to their shared generational history. Both writers chart the toll a certain version of middle class heteronormativity has taken historically on women, from the 1950s through the 1980s. ("Come in from the Cold" came out on Night Ride Home in 1991; Atwood's Cat's Eye came out in 1988); Mitchell and Atwood both portray the ways in which femininity was instilled and policed by their 1950s Canadian upbringing. Think of the first line of "Come in from the Cold": "Back in 1957 we had to dance a foot apart." The oppressive chaperoning of the 1950s high school dance ignites a lifetime of erotic yearning that suffuses the rest of the song as we listen to the narrator grow older, although not necessarily wiser-- still longing for the sexual frisson of youth. Both Mitchell and Atwood are sceptical about the idea that growing older means gaining wisdom. The analysis that underpins these self-critical lines, and takes apart the romantic spark, are uncompromisingly honest: “Are you just checking out your mojo? Am I just fighting off growing old?" But as the singer ages, she emphasizes a continued shared vulnerability and neediness in relation to romance, hurting and panicking- "we strike out/out of fear." 10

Atwood covers similar terrain in Cat's Eye. There's an uncompromising, scratchy, clear-sightedness in the way they portray women's desire for men, for art, and for freedom-showing women breaking away from heteronormative narratives of desire and getting sucked back in again, knowing the stakes and dangers but unable to fully extricate themselves. This 
problem-- the contradictions of heterosexuality, of being caught in a certain version of romance, and of the myths surrounding the female artist-- can be tragic, but also funny, a point to which I will return at the end. A line such as this from Cat's Eye, "Old lovers go the way of old photographs, bleaching out gradually as in a slow bath of acid" would not be out of place in a Mitchell song such as "Down to You": "Everything comes and goes/marked by lovers and styles of clothes."11

Atwood and Mitchell have some obvious biographical similarities. They are of the same generation, only a few years apart in age: Atwood was born in November 1939 and Mitchell was born in November 1943. They shared a childhood in the 1940s shadowed by World War II, and the sometimes harsh conditions of small town Canadian life. Mitchell talks about the kinds of texts which influenced her as a child in an interview with Malka Marom:

There were only two stores in town. My dad ran the grocery store and Marilyn McGee's dad ran the general store. She and I called the Simpsons-Sears catalogue "The Book of Dreams." It was so glamorous when I was a child, four or five. We'd be down on our bellies looking at every page, and she and I would pick out our favourite object from the front page to the back page. We would cut out our favourite matron's girdle and our favourite saw and our favourite hammer. "I like that one best." Every page, “That's my favourite." So in that way you learned to shop before you have money, you learn the addiction of the process of selection... ${ }^{12}$

The Sears catalogue signifies a kind of constricted feminine consumerist fantasy, but also a sense of play and enjoyment: the young girl's right to have desires. However, contained in the material reality of the fantasy is also a harsh reminder of economic reality: "The Book of Dreams, when everybody had read it, because we were on rations, it became toilet paper. Even the mayor, if you could imagine, wiped his ass with the Simpsons-Sears catalogue, 
glossy coloured paper." ${ }^{13}$ In Cat's Eye, Atwood shows her character Elaine, as a young girl, cutting up the Eaton catalogue in a kind of bewildered conformity with the games her friends Grace and Carol want to play:

Or we sit on the floor in Grace's room with piles of old Eaton's Catalogues. I've seen lots of Eaton Catalogues before: up north they're hung in outhouses for use as toilet paper. Eaton's catalogues always remind me of the stench of such outhouses, the buzzing of the flies down the hole underneath[...]But here we treat these catalogues with reverence. We cut the small coloured figures out of them and paste them into scrapbooks. Then we cut out other things-cookware, furniture-- and paste them around the figures. The figures themselves are always women. We call them "My lady." "My lady's going to have this refrigerator," we say. "My lady's getting this rug." "This is my lady's umbrella."14

These games, in which store catalogues become "books of dreams" for young girls aspiring towards domestic bliss in 1940s Canada, and then are used to wipe up shit, indicate that 1940s and 50s fantasies of the "good life" never go unquestioned in Mitchell's and Atwood's works. ${ }^{15}$ Cat's Eye, in its brutal depiction of cruel and bullying friendships between girls, proceeds to dismantle this domestic idyll for girls, exposing the anxieties and fears of otherness that grounds the dream of romance, marriage, and buying refrigerators. Mitchell's "Song for Sharon" from Hejira mines some similar territory, comparing the singer's grappling with fame and love to the different path of a childhood friend. As a child, the singer wanted romance and the wedding dress most of all: "the ceremony of bells and lace/still veils this reckless fool here." Sharon ends the song with a husband and a farm, while the singer has "the apple of temptation/ and a diamond snake around [her]arm." The desire to connect to the childhood girlfriend, who understands the woman artist and what made her 
who she is, is intense and palpable in both "Song for Sharon" and Cat's Eye. The crushing effects of female competitiveness and cruelty are foregrounded in Atwood's novel, yet the protagonist Elaine ends the book with a sense of longing for the lost frenemy who nearly destroyed her life as an adolescent: "This is what I miss, Cordelia: not something that's gone, but something that will never happen. Two old women giggling over their tea." ${ }^{\prime 16}$ Addressing an old friend provides more comfort in "Song for Sharon" amidst the comparisons between the singer's life and Sharon's. Many of Mitchell's songs chart the contortions of the woman artist unsuccessfully attempting to have both romance and a creative identity; however, the end of "Song for Sharon" gives both Sharon and the singer music and the landscape of their childhood ("I've still got my eyes on the land and the sky"). ${ }^{17}$ The friendship between women seems alive and potentially nourishing, at least in this telling.

Time and location also connect Mitchell's work to Atwood's. Both were teenagers in the 1950s, and both negotiated the complex and fractious business of being a woman artist in the 1960s and beyond. Further, their Canadian roots are central to their work. They both write about the geography of Canada, taking its skies, rivers, mountains and clouds as metaphors and backdrops. As Atwood puts it: "One of the primary interests for a Canadian writer has to be geology followed by geography."18 Rocks and maps, vast spaces and bodies of water, populate their art. As Mitchell claims of her relationship to the Canadian landscape: "I've always thought Neil [Young] and I [... ]carried a loping prairie walk in our music..."19 There is, I think, a specifically Canadian sense of loneliness here, that combines with the possibility of completion in the landscape; wandering through it, facing the cold, and not just coming in from it, will get you somewhere. ${ }^{20}$

Many of Mitchell's reminiscences of her childhood in Michelle Mercer's Will You Take Me As I Am: Joni Mitchell's Blue Period and Malka Marom's book of interviews, Both 
Sides Now, chime deeply with Atwood's portrayal of the harsh winters the adolescent girls experience in Cat's Eye. Mercer writes:

Every year in early spring, Joni remembers, she and her best friend Sharolyn would wait for the day the ice broke on the Saskatchewan River. They'd head to the river bluffs after school, looking for signs the big event was coming. Snow and ice slowly melted into the water, which then rose under the surface ice and began to degrade it [...]They watched closely for cracks because once the break started it was over quickly and they didn't want to miss it. When this rite of spring finally came, its violence was mesmerizing, the great plates of splitting ice sounding like rifle shots, or sometimes cannon booms. The broken ice chunks thudded and crashed downstream, pulling along trees torn from the riverbank and whatever else didn't get out of the way. With a couple of days, the ice would be gone. ${ }^{21}$

The ice and thaw are central for Atwood too. In a traumatic central scene in Cat's Eye, Elaine, abandoned by her bullying, torturing school friends, falls through the ice. Something about this chilling, menacingly violent, but also potentially freeing version of mother nature resonates for both artists, who often seem to be skating on thin emotional ice. In an interview with Malka Marom, Mitchell talks about her reasons for leaving the sometimes-idyllic Laurel Canyon, as a longing for a remembered Canadian harshness:

It's like when I left my house in Laurel Canyon, which seemed too soft and too comfortable, too dimly lit, too much red upholstery [...] And the place that I built up on my land in British Columbia was almost like a monastery [...] Stone and hardwood floors and hardwood benches. Everything that would be corrective. No mirrors [...] I made this place very uncomfortable, like a corrective shoe. ${ }^{22}$ 
Mitchell and Atwood both chafe at a version of softness that is so often ascribed to women artists; what I am calling their irritable Canadian feminism is itself a kind of corrective, an ethics and aesthetics of the uncomfortable place. In her book on Canadian literature, Atwood suggests that if the USA claims the frontier as a central organising symbol, and England, the island, the central symbol for Canada is "survival."23 Survival as an idea is multi-faceted, Atwood suggests, "For early settlers or explorers it meant bare survival in the face of 'hostile' elements and/or natives: carving out a place and way of keeping alive. But the word can also suggest survival of a crisis or disaster, like a hurricane or wreck, and many Canadian poems have this kind of survival as a theme; what you might call 'grim' survival as opposed to 'bare' survival." ${ }^{24}$ Atwood and Mitchell both face, and work with grim survival. It limns their ways of being women artists. ${ }^{25}$

There are other more mundane biographical connections between Mitchell and Atwood as well; they both lived in the same neighbourhood in Toronto, and perhaps most obviously, they know each other. Atwood paid tribute to Mitchell in a speech inducting her into the Canadian Songwriters Hall of Fame in 2007, and they received stars on Toronto's Walk of Fame at the same time. Atwood reflects on this in a 2012 interview: thinking about the perks of being Margaret Atwood, she says: "Winning the Booker after three previous nominations-- that was certainly a lot of fun[...] Getting the Toronto Walk of Fame with Joni Mitchell-- that was fun because it was Joni Mitchell." ${ }^{26}$ I have not found any evidence of Mitchell talking about Atwood's work, but there is a lovely photograph of the two hugging after attending the unveiling of their stars on the Canada Walk of Fame in October, 2001. ${ }^{27}$ Mitchell is on record as being a fan of another great Canadian fiction writer, Alice Munro, and the thematic connections between Munro and Mitchell are strong as well. ${ }^{28}$ These three fierce modern Canadian women writers all write about female desire, and the way it is 
punished and disciplined, with wry humour as well as, more than occasionally, despair. One of my favourite Mitchell lines, from "The Same Situation" off Court and Spark "Send me somebody who's strong and somewhat sincere" does not dismiss the possibility of love entirely, but it weighs in with diminished expectations. It's a line that might well appear in a story by Munro or Atwood. Is there a specifically ambivalent shared Canadian feminist sensibility that these women writer share? To speculate via potentially dubious stereotypes, I wonder if the imperative on the Canadian woman isn't doubled; women are required by our heteronormative, patriarchal culture to be nice, to placate, to show an idealized maternal unselfishness, always thinking of others before themselves. Canadians are often stereotyped as nice as well. Is it possible that writers like Mitchell, Atwood, maybe Munro, claim an artist's version of self and ego in response to these imperatives? A connection to desire and freedom that is refracted through a cold and sometimes harsh landscape, a refusal to placate men, that codes as doubly ornery for Canadian women?

The two artists' shared thematics do not end there. Atwood's first book of poetry was called The Circle Game, and came out in 1964, shortly before Mitchell wrote her song "The Circle Game" which was covered by Tom Rush and Buffy Sainte-Marie before Mitchell herself recorded a version of it for Ladies of the Canyon (1970). ${ }^{29}$ If you Google "circle games" (rather than "the circle game") you get a list of kids' party games such as Duck, Duck Goose. The idea of "circle games" was available as a metaphor in the early $60 \mathrm{~s}$, but it is Mitchell's song that lingers in people's memories when you mention the phrase. Atwood's poem of that title does not simply mirror Mitchell's use of the phrase. Mitchell's image of the carousel as childhood, the seasons of life going around in a movement of hopeless and hopeful aging and return, contrasts with Atwood's less reassuringly cyclical image of "circle games," although Atwood's poem also refers to childhood games. In Atwood's poem, the circles are enclosing and entrapping for the woman speaker: "So now you trace me/like a 
country's boundary/or a strange new wrinkle in/your wellknown skin." ${ }^{30}$. The imagery of the circling children's game, and some of the language is similar: "The children on the lawn/joined hand to hand/go round and round..."31 In Atwood's poem, the childhood game turns sinister and a circle must be broken; whereas, for Mitchell, the carousel of time is inevitable for everyone, and comforting at least in the beauty of the song, and the promise of renewal. ${ }^{32}$ Is there a clear connection between the two circle games? According to the Joni Mitchell website, Joni introduced "The Circle Game" at a concert in 1966 while Atwood's "Circle Game" poem sequence was first published in a magazine, and then in book form in 1964. ${ }^{33}$ Mitchell's song was written in response to Neil Young's "Sugar Mountain”, which was composed when Young was 19 and unhappy at the thought of growing older ("You can't be twenty on Sugar Mountain"). "The Circle Game" as a response to Young, is less despairing and more reflective. It also shifts the imagery of the childhood competitive version of the circle game. In Duck, Duck, Goose, someone is always It, the goose, the loser, while the carousel symbolises a race that never ends and which the child can never win, partly because we all grow old and die, but also because winning is not the point. In Mitchell's "Circle Game" living is the point.

Margaret Atwood said in response to a tweeted question, that she has "never known" whether Joni knew of her poem sequence, but the shared sensibility, emerging from the shared Canadian literary and artistic scene is strong. ${ }^{34}$ From this 40 s-60s backdrop of emerging progressive politics, played out in cold places, comes their shared wry humour and their "irritable feminism" in relation to heterosexual relations. I want to suggest that, amongst other things, Mitchell's songs twist romance in unexpected ways. Her songs allow us to see relations between men and women as romantic: seductive, attractive and exhilarating but also, as well as being dangerous, they are often, also perhaps doomed from the start, rooted in lies. The best you can hope for in a man is "somewhat sincere". Mitchell's perspective also 
meshes with her interest in original sin, as in "Woodstock""s wish to "get ourselves back to the Garden." However, if from one point of view, the sexual relation is originally constituted by a tragic curse, then, from another less grandiose perspective, it is just kind of annoying. Kind of inevitable. Something to be laughed at, as well as cried along with. Hence my title, "Here's a man and woman sitting on a rock" from "Hejira". The visual, deictic gesture -"Here's"-- makes it seem as if the listener chances upon this couple, as the last or only people on earth, mythical, stranded only each other. "They're either going to thaw out or freeze" suggests this is an Adam and Eve myth playing out on a desert island. This is a back-tobasics gesture that suggests not so much an ideal original pairing, but a continually evolving lovers' quarrel, a Huis Clos of relationships. ${ }^{35}$

In Mitchell's love songs which are often also irritated-with-love songs, there is often an assumed-to-be-confessional portrait of a woman artist finding ways to be taken seriously, to take herself seriously. But within this structure she encounters a moment when she also turns a harsh eye back on herself, allowing for the sense that perhaps she also has been taking herself too seriously. This back and forth between melodramatic desires for freedom, and realisations of the potential comforts of self-deflation, of ordinariness, or a lack of transcendent meaning, is characteristic of Mitchell's work. In "Come in from the Cold" she looks back on a time when she though life had meaning, and she had choices to make, "And I made some value judgements/In a self-important voice." Mitchell recognises the absurdity of the grand claim, especially in relation to the vicissitudes of love and desire; however, she still longs "to lose control." Clear-sightedness resides in the moment that you excuse no one, even or especially yourself, from your own canny judgemental eye.

In a song she has referred to as one of her own favourites, "Refuge of the Roads" off Hejira, Mitchell turns her amused and deflationary gaze outwards and then inwards. ${ }^{36}$ I will conclude by talking a little about the first and last verses of this song. It begins by recalling a 
meeting with a charismatic man, "a friend of spirit" who drinks and womanizes, but who also becomes a part of an intense relationship —almost a folie à deux-- with the singer, who sees herself in him, and him in herself. "He saw my complications and he mirrored me back simplified/And we laughed at how our perfection would always be denied." Up to this point in the song there is a characteristic wry doubled recognition; the two of them are mirrors of each other, awesome, perfect. It's just such a shame that so few others realise it. But then the man takes a funny turn, dispensing words of wisdom to the singer. He starts telling her what to do to make herself more content, that she needs "heart and humour and humility" to lighten her burden. Is it any wonder she abandons him for the roads?

Putting aside, for a moment, Mitchell's on-record statement that the song is about the Buddhist spiritual leader, Trungpa, who was making the celebrity rounds in the early 1970s, this first verse is interesting to me because it seems to portray a relationship of equals. ${ }^{37}$ (I say "relationship" because I think it does not matter much whether it's a relationship between friends or lovers). Although the man "drinks and womanizes" and the woman, initially, seems charged with holding him together, grounding the man's sanity in her tears, this dynamic quickly shifts. On the one hand, he seems to really see her-there's a mutual recognition between them, and she is complicated. Being "simplified" for her is not a bad thing. And they are funny together - in their shared egotism, laughing at how their perfection will always be denied. This is unusual - what other portrayals of heterosexual relationships can you think of, especially in pop music, in which both participants joke about their own shared narcissism $?^{38}$ But then, as the verse finishes, he ruins it all by mansplaining enlightenment, and she leaves. Heart and humility might be nice in the abstract, but not coming from him, not to her. She's got other fish to fry. I find here that wry, amused, refreshingly unforgiving, reaction to heterosexual role-playing that I am calling Canadian, irritable feminism. 
The rest of the song charts her wandering away from the one on one connection towards something freer - she falls in with drifters and cooks them dinner, finds fun in cities, listens to the crickets while losing herself in nature. There is a movement here away from individual enlightenment, or the fulfilment a woman might hope to find in a romantic entanglement, towards an itinerant sense of community and the intense freedom, the aloneness and possible connection, of travel. In the final verse of the song she is in the most mundane of places, a highway service station, looking at a famous photograph of the earth taken from the moon. The first of these photographs dates from August 23, 1966, and several famous ones followed in the late 1960s and early 1970 s. ${ }^{39}$ When used on the cover of the countercultural consumer bible, The Whole Earth Catalog in 1968, and in many other contexts, these photographs become inseparable from a sense of infinite possibility for humanity; yet they also suggest a humbling sense of scale. The photo in the gas station sets the scene for what follows in the song, what you can and can't see when you see the earth whole:

...you couldn't see a city

On that marbled bowling ball

Or a forest or a highway

Or me here least of all

The final objects that can't be seen in this grand photograph, after the artist herself, are the mundane and unpleasant details of travelling-restrooms without hot water, luggage that is bursting at the seams. The ending of the song is all about perspective-moving out and moving in again. The roads, in the final verse, lead to the stars - to the point where the selfseeking, free, woman artist, is no longer visible, even to herself. "Refuge of the Roads" charts a characteristic version of perspective in Mitchell's work; how could one hope to find a 
single individual on the earth as seen from the sky? But perhaps this disappearance of the female self - the me who is invisible-- is also a kind of glorious reassertion, a shot in the dark from the woman artist, staking a claim for freedom against the mansplaining egocentrism of the first verse. Like Atwood, her sister in irritable Canadian feminism, I see Mitchell as finally very happy, as the song says, to keep "mak[ing] most people nervous", with her unforgiving and unforgettable analyses of the truths and lies people tell to themselves about their own significance, and their feelings for others, in relationships and in solitude. Whether Mitchell and Atwood would grudgingly acknowledge my "irritable feminism" label or, dismiss it with a characteristic desire for freedom, an insistence on not being pinned down, for me, their exasperated, wry, funny, sometimes grim, Canadian feminism is, and will continue to be, an extraordinary refuge, charting an ethics and aesthetics of some of the late $20^{\text {th }}$ century's most uncomfortable places.

\section{Works Cited:}

Atwood, Margaret. (1990), Cat's Eye. London: Virago.

-- (1964), "The Circle Game" in The Circle Game. Contact Press.

-- (1985), The Handmaid's Tale. Canada: McClelland and Stuart Ltd.

-- (1972), Surfacing. McLelland and Stewart Ltd.

-- (1972), Survival: A Thematic Guide to Canadian Literature. Toronto: House of Anansi Press.

Berlant, Lauren. (2011), Cruel Optimism. Durham: Duke University Press. 
Dobrian, Joseph. (February 7, 2017) “'Song for Sharon' brings back memories” Iowa City Press Citizen. http://www.press-citizen.com/story/opinion/contributors/writersgroup/2017/02/07/joni-mitchell-song-sharon-brings-back-memories/97296996/

Ferriera, Becky. (August 23, 2016) "The First Photographs of the Earth from the Moon Were Taken 50 Years Ago Today." https://motherboard.vice.com/en_us/article/bmvyzw/the-first-photographs-of-the-earth-fromthe-moon-were-taken-50-years-ago-today

Fischer, Doug. (October 8, 2006), “The Trouble she’s seen”, Ottawa Citizen, http://jonimitchell.com/library/view.cfm?id=1459

Gunn, Frank. "Author Margaret Atwood, left, and singer Joni Mitchell hug each other after unveiling their stars on the Canada Walk of Fame in Toronto on Friday Oct. 19, 2001."Baltimore Sun, http://www.baltimoresun.com/la-et-ms-joni-mitchell-pictures20150331-005-photo.html

Kirk, Andrew G. (2007), Counterculture Green: The Whole Earth Catalog and American Environmentalism, Lawrence: Univ. of Kansas Press.

Lorde. (2017), “The Louvre”, Melodrama.

Marom, Malka and Joni Mitchell. (2014), Joni Mitchell: Both Sides Now-Conversations with Malka Marom. Omnibus Press. 
McNamara, Mary. (April 24, 2017), “Q and A: Margaret Atwood answers the question 'Is The Handmaid's Tale a Feminist Book?"' LA Times.

Mead, Rebecca. (2017), "Margaret Atwood: The Prophet of Dystopia". The New Yorker, April 27, 2017. http://www.newyorker.com/magazine/2017/04/17/margaret-atwood-theprophet-of-dystopia

Mercer, Michelle. (2009), Will You Take Me As I Am: Joni Mitchell's Blue Period. Backbeat Books.

Mitchell, Joni. (1970), "The Circle Game”, Ladies of the Canyon.

(1988), "Come in from the Cold", Night Ride Home.

(1970), “Conversation”, Ladies of the Canyon.

(1974 ), "Down to You", Court and Spark.

(1976), "Hejira”, Hejira.

(1976), "Refuge of the Roads", Hejira.

(1971), "River", Blue.

(1974), "Same Situation”, Court and Spark.

(1976), “Song for Sharon”, Hejira.

(1970), "Woodstock", Ladies of the Canyon.

Song Facts: "The Circle Game" by Joni Mitchell

http://www.songfacts.com/detail.php?id=5649, accessed 13 July 2017. 
Weller, Sheila. (2008), Girls Like Us: Carole King, Joni Mitchell, Carly Simon -- and The Journey of a Generation. New York, NY: Atria Books.

Woolf, Virginia. (1998) Between the Acts. Oxford: Oxford World's Classics.

\footnotetext{
${ }^{1}$ I'd like to thank Ian Balfour and Ruth Charnock for their editorial contributions to this chapter. Wild speculations and wrong stuff is, of course, all my own fault.

${ }^{2}$ Lauren Berlant, Cruel Optimism (Durham: Duke University Press, 2011).In Cruel Optimism Lauren Berlant argues that an attachment to an object that is not conducive to our thriving structures the affective state she names cruel optimism. I am suggesting that Mitchell and Atwood both have a strongly self-reflexive attitude toward this state.
}

${ }^{3}$ Malka Marom and Joni Mitchell, Joni Mitchell: Both Sides Now-Conversations with Malka Marom (Omnibus Press, 2014), 62.

${ }^{4}$ Mary McNamara. "Q and A: Margaret Atwood answers the question 'Is The Handmaid's Tale a Feminist Book?"” LA Times, 24 April 2017.

${ }^{5}$ Rebecca Mead, "Margaret Atwood: The Prophet of Dystopia”, The New Yorker, 27 April 2017, http://www.newyorker.com/magazine/2017/04/17/margaret-atwood-the-prophet-of-dystopia ${ }^{6} \mathrm{http}: / / \mathrm{www}$. luminarium.org/contemporary/atwood/atwood.htm

${ }^{7}$ Margaret Atwood Cat's Eye (London: Virago, 1990), 50.

${ }^{8}$ Atwood, Cat's Eye, 90.

${ }^{9}$ Think in Mitchell of a song such as "Conversation" in which the lover has not sympathy whatsoever for the mistreated partner of the man she is in love with: "She only takes him out to show her friends/I want to free him.” (Mitchell, “Conversation” (1970))

${ }^{10}$ Mitchell, "Come in from the Cold" (1988).

${ }^{11}$ Atwood, Cat's Eye, 266; Mitchell, "Down to You” (1974).

${ }^{12}$ Marom and Mitchell, Joni Mitchell, 2-3. 
${ }^{13}$ Marom and Mitchell, Joni Mitchell, 13-14.

${ }^{14}$ Atwood, Cat's Eye, 53

${ }^{15}$ Leopold Bloom similarly wipes his ass with a newspaper in James Joyce's Ulysses in a commentary on the tabloids.

${ }^{16}$ Atwood, Cat's Eye, 421.

${ }^{17}$ Song for Sharon" is dedicated to Joni's best friend when she was growing up in Maidstone, Saskatchewan in the 1950s. It refers to the fact that Sharon wanted to be a professional singer, while Joni wanted to get married and live on a farm. As adults the two changed places. (Joseph Dobrian, "Song for Sharon' brings back memories")

${ }^{18}$ Michelle Mercer, Will You Take Me As I Am: Joni Mitchell’s Blue Period. (Backbeat Books, 2009), 51-52

${ }^{19}$ Mercer, Will You, 53

${ }^{20}$ Think for instance of Mitchell's "River" from Blue, where a river is both something frozen, but also a means of escape after a ruined love affair, something "to skate away on."

${ }^{21}$ Mercer, Will You, 64.

${ }^{22}$ Marom and Mitchell, Joni Mitchell, 87.

${ }^{23}$ Atwood, Survival: A Thematic Guide to Canadian Literature, (Toronto: House of Anansi Press, 1972), 31.

${ }^{24}$ Atwood, Survival, 32.

${ }^{25}$ Drowning in cold water is also a threat and a promise for both artists. See for instance, Mitchell, "Song for Sharon" and Atwood, Surfacing and the poem "This is a photograph of me" from The Circle Game.

${ }^{26}$ ((http://www.womenofinfluence.ca/2012/09/10/margaret-atwood-success-story/)

${ }^{27}$ http://www.baltimoresun.com/la-et-ms-joni-mitchell-pictures-20150331-005-photo.html

${ }^{28}$ Quoted in Mercer, Will you , 208-9. taken from “Idol Talk,” Sean O’Hagan, New Musical Express, June 4, 1988 (208-9) Joni pictures herself as a frustrated short story writer "You heard of Alice Munro? Boy! I connect with her. She's a fellow Canadian and she writes about things I lived through. But I kinda slept through them. I didn't absorb them like her-- detailed memories of childhood, family gatherings, events. I used to look to Dylan or Neil [Young] for songwriting inspiration but now, there's no one really cutting it, so you gotta turn to the short story tellers-- Munro, Raymond Carver, the dirty realists. Since The Hissing of Summer Lawns, I've been a frustrated short story writer but whereas Carver makes me think I can write short stories, Munro makes me think I can't." 
${ }^{29}$ Buffy Sainte-Marie was the first to release it on her 1967 album Fire and Fleet and Candlelight. Tom Rush also recorded the song, making it the title track of his 1968 album. This was a breakthrough for Mitchell, who spent much of 1967 performing in Philadelphia and Toronto as she built up her career. Rush saw her perform in Detroit that year, and recorded "The Circle Game" along with two other Mitchell compositions for the album: “Urge For Going” and “Tin Angel.” Mitchell's own version came out in 1970 on Ladies Of The Canyon. (http://www.songfacts.com/detail.php?id=5649)

${ }^{30}$ Margaret Atwood, The Circle Game (Contact Press, 1964)

${ }^{31}$ Margaret Atwood, The Circle Game (1964)

${ }^{32}$ This might have to do with the way the two texts are gendered. Mitchell's "Circle Game" is about a boy ("words like when your older must appease him") whereas Atwood's "Circle Game" is about a woman trapped in a relationship.

${ }^{33}$ http://www.songfacts.com/detail.php?id=5649

${ }^{34}$ Twitter, 7 January 2018. Atwood responded to my question about whether she knew of any relationship between her book and Mitchell's song: "I have never known that, but my poem sequence (inside the book and pub'd in a mag earlier than it) predated the song. I think more likely just coincidence tho."

${ }^{35}$ One might consider this in relation to the ending of Virginia Woolf's final novel, Between the Acts, in which an estranged couple who have not spoken to each other for the entire book, finally open their mouths to speak, in front of a barren landscape, seemingly disembodied in time: "Isa let her sewing drop. The great hooded chairs had become enormous. And Giles too. And Isa too against the window. The window was all sky without colour. The house had lost its shelter. It was night before roads were made, or houses. It was the night that dwellers in caves had watched from some high place among rocks.

Then the curtain rose. They spoke." (Virginia Woolf, Between the Acts (Oxford: Oxford World's Classics, 1998) 197)

\footnotetext{
${ }^{36}$ Weller, Sheila (2008). Girls Like Us: Carole King, Joni Mitchell, Carly Simon -- and The Journey of a Generation. New York, NY: Atria Books. p. 415.
} 
${ }^{37}$ Doug Fischer, "The Trouble she's seen,” Ottawa Citizen, October 8, 2006

(http://jonimitchell.com/library/view.cfm?id=1459);_Mercer, Will you take me as I am: Joni Mitchell's Blue Period (Backbeat Books, 2009), 202.

${ }^{38}$ I think of a recent inheritor of Joni's romantic sensibility, Lorde, whose song "The Louvre" contains a similar gesture when she claims that she and her lover are so awesome that they should hang them in the Louvre, "down the back, but so what? Still the Louvre" (Lorde, "The Louvre", Melodrama)

${ }^{39}$ Becky Ferriera, “The First Photographs of the Earth from the Moon Were Taken 50 Years Ago Today", August 23, 2016. 